\title{
New Adsorbent from Red Beet Roots (CRBR) for Removal of Lead
}

\author{
Y. Walid Al Bizreh ${ }^{1}$, Emtisal Hamada $^{1^{*}}$, Malak Aljoubbeh ${ }^{2}$ \\ ${ }^{1}$ Department of Chemistry, Faculty of Sciences, Damascus University, Syria. \\ ${ }^{2}$ Department of Chemistry, Faculty of Sciences, Damascus University, Syrian Private \\ University, Syria.
}

\begin{abstract}
$\mathbf{T}$ HE MAIN purpose of this work is to remove lead ions from aqueous solution by using carbon of red beet roots (CRBR). The influence of contact time, initial concentration, temperature, $\mathrm{pH}$ of solution and the dose of adsorbent were studied. It was found that the maximum removal percentage of $\mathrm{Pb}$ (II) has reached $99.99 \%$ at room temperature by applying the following conditions: adsorbent loading weight $0.1 \mathrm{~g}$, contact time $24 \mathrm{hrs}$, and 9.993 $\mathrm{m} . \mathrm{mol} / \mathrm{L}$ concentration of lead ions. The adsorption process of $\mathrm{Pb}(\mathrm{II})$ on $\mathrm{CRBR}$ was of chemical nature and followed the kinetic formula of pseudo second -order reaction. Results of FTIR spectroscopy and scanning electron microscopy made it possible to propose mechanism for the adsorption process. The recovery of the adsorbed $\mathrm{Pb}(\mathrm{II})$ ions on CRBR surface was done by using $1 \mathrm{~N}$ acetic acid solution resulting a recovery of $87.466 \%$.
\end{abstract}

Keywords: Red beet roots, Removal of lead, Adsorption.

\section{Introduction}

Nowadays, there has been a great concern about the raises of water pollution on the human and environmental, that can be caused by industrials effluents and wastes generated by activities of modern life [1]. Among the several types of water contaminats, heavy metals are one among the foremost necessary environmental issues that has got to be resolved, and established ways to get rid of them. [2]. Many conventional methods exist for the removal of heavy metals from wastewater [3]. These methods include chemical precipitation, coagulation, solvent extraction, electrolytic process, membrane separation, and ion exchange [4]. These methods have several disadvantages such as producing a large amount of toxic sludge and high costs. Adsorption using low cost adsorbents is the alternative process for removal of heavy metals from aqueous solutions [1].

Among the different heavy metals lead is one of the common and most toxic pollutants because it accumulates within the brain, bones, kidneys, muscles, and causes a series of disorders like anemia, uropathy and neurologic epidemic disorders that result in death [2]. In drinking water maximum allowable limit of total $\mathrm{Pb}$ of $50 \mu \mathrm{gL}^{-1}$ considered safe by the World Health Organization, whereas less than $15 \mu \mathrm{gL}^{-1}$ is adopted by the United States Environmental Protection Agency [5]. Adsorption of lead was studied by using adsorbents of agricultural origin such as tea leaves [2], the waste pulp of sugar beet[4], rice husk [6], sago waste [7], tea waste [8], date tree leaves [9], tridax procmbens plant leaves [3], rice husks, maiz cobs and sawdust [10].

Natural materials were also used for removing the lead ions from wastewater, where the removal of lead ions was studied by using the American bentonite [11], the result of this study has shown that bentonite was more effective natural material for removing the lead ions from aqueous solution than activated carbon [11].

Recently different adsorbents have been used for removal of lead ions such as carbon of sewage sludge[12], activated lawsonia inermis carbon[13], rice straw[14], and livestock biomasses[15].

This work focuses on the adsorption of lead ions from aqueous solution by using carbon of red beet roots (CRBR) without modification, The reason for using red beet roots is its availability in local area in large quantities with low cost and for being highly effective material for removing heavy metals.

\footnotetext{
*Corresponding author e-mail: emtessal-hamada@hotmail.com DOI: 10.21608/EJCHEM.2018.3904.1342

C2019 National Information and Documentation Center (NIDOC)
} 


\section{Materials and Methods}

Preparation of adsorbent (CRBR)

A sample of dried red beet roots was inserted in a cylinder and calcinated for $4 \mathrm{hrs}$ at $400{ }^{\circ} \mathrm{C}$ followed with further calcination for $4 \mathrm{hrs}$ at $600^{\circ} \mathrm{C}$, then it was cooled to reach the room temperature. The carbon was characterized by using PC X Ray Fluorescence (X-MET 5100-Oxford instrument), JASCO- FT-IR 4200 device, Scanning Electronic Microscopy (SEM, VEGA $\ \backslash \mathrm{XMU}$ ) coupled with Energy Dispersive X-ray Analysis (EDAX-AMETEX).

\section{Preparation of lead solution}

A stock solution $(2070.5 \mathrm{mg} / \mathrm{l}$ or 9.993 $\mathrm{m} . \mathrm{mol} / \mathrm{L})$ of $\mathrm{Pb}(\mathrm{II})$ ions was prepared by dissolving an accurately weighed analytical grade lead nitrate(RIEDEL-DE-HAEN AGSEELZEHANNOVER, in deionized water $(\mathrm{pH}=5.27)$. Studied solutions of different concentrations, as required, were prepared from the stock by dilution process. Lead ions concentration was measured by using an atomic absorption device (AuroraAI1200 instrument).

\section{Procedure of adsorption process}

$5 \mathrm{ml}$ of lead nitrate solution were powered into each of glass tubes containing $0.1 \mathrm{~g}$ of CRBR to study the impacts of contact time, $\mathrm{pH}$ solution, initial concentration of lead and change of temperature during the adsorption process.

\section{Results and Discussion}

\section{Adsorption characterization}

Morphological studies

The surface of CRBR was analyzed by scanning electronic microscopy coupled with energy dispersive X-ray analysis. The results of SEM for CRBR before and after adsorption of lead ions are shown in Fig. 1a and 1b.

The SEM image (Fig. 1a) shows the irregular texture of pores on the surface of adsorbent. The diameters of some pores were between (8.46 23.98) $\mu \mathrm{m}$. Figure $1 \mathrm{~b}$ shows the surface of CRBR after adsorbing lead (II) ions. Deposits of adsorbentadsorbate complex are observed on the surface of the adsorbent following the interaction with $\mathrm{Pb}(\mathrm{II})$ ions. EDXA analysis of some spots on the surface of CRBR before and after adsorption was carried out and listed in Tables 1 and 2 respectively.

As shown in Table 2 lead and nitrogen elements appeared on the surface of CRBR after the adsorption process.

Figure 2 shows the EDXA analysis for CRBR after adsorbing lead ions on it. The appearance of $\mathrm{Pb}$ and nitrogen on the surface of CRBR after the adsorption corresponds to values 2.34 and 10.58 $\mathrm{KeV}$ for $\mathrm{Pb}$ [16] and $0.392 \mathrm{KeV}$ [17] for nitrogen indicating the presence of both ions (lead and nitrate)on the surface of CRBR.

\section{$X R F$ Analysis of CRBR}

Chemical composition of CRBR before adsorption was studied by using PC X Ray Fluorescence (X-MET 5100-Oxford instrument). The results of XRF analysis are listed in Table 3.

\section{Infrared Spectroscopic Studies}

The FT-IR spectra of CRBR before and after adsorption of lead ions were taken by using jasco FT-IR -4200 device. Figure $3 \mathrm{a}$ shows the FTIR spectra of CRBR before adsorption of $\mathrm{Pb}(\mathrm{II})$ ions. Figure $3 \mathrm{~b}$ demonstrates the FT-IR spectra of
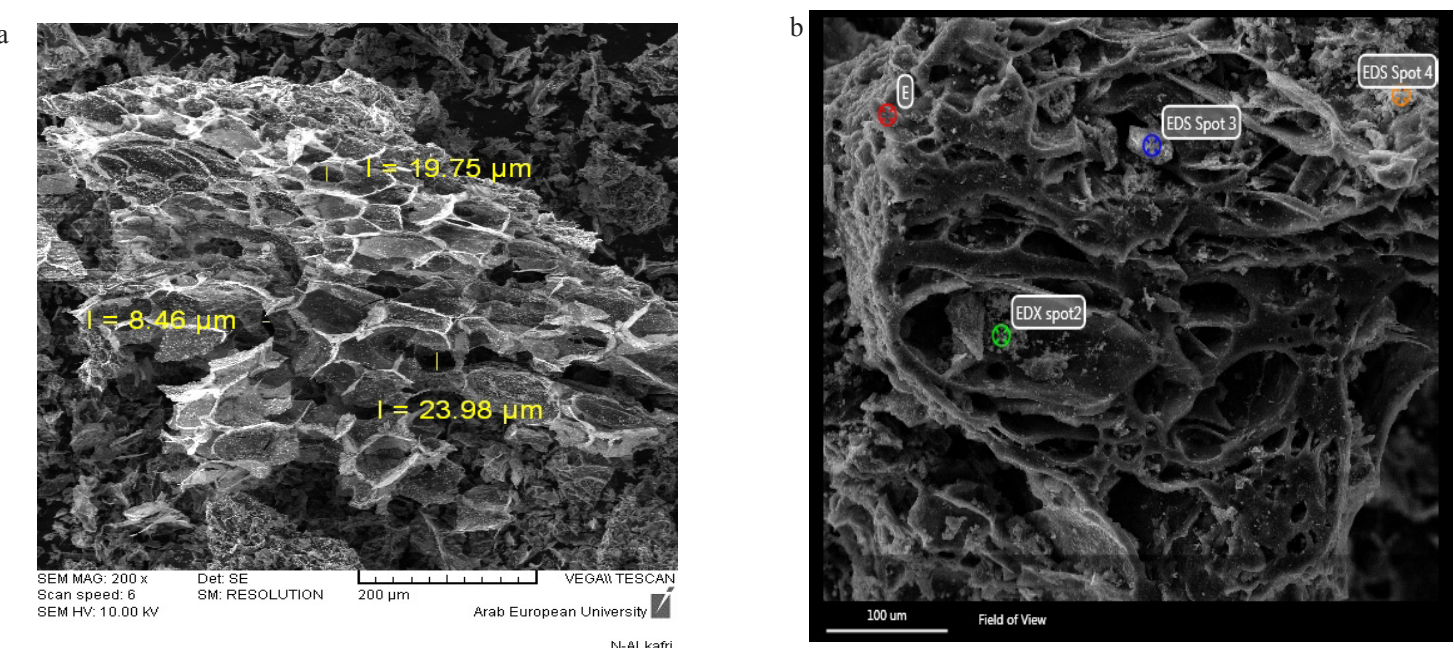

Fig. 1. SEM image of CRBR (a) before adsorption (b) after adsorption. 
TABLE 1. EDXA analysis of some spots on the surface of CRBR before adsorption of lead ions

\begin{tabular}{cccccc}
\hline Spot 4 (wt \%) & Spot 3 (wt \%) & Spot 2 (wt \%) & Spot 1(wt \%) & Full area (wt \%) & Element \\
\hline 54.74 & 48.57 & 49.65 & 46.71 & 54.67 & $\mathrm{C}$ \\
26.88 & 25.19 & 16.82 & 23.81 & 25.87 & $\mathrm{O}$ \\
7.51 & 9.05 & 9.45 & 9.18 & 7.42 & $\mathrm{Na}$ \\
0.38 & 0.35 & 0.36 & 0.46 & 0.38 & $\mathrm{Mg}$ \\
0.02 & 0 & 0.05 & - & 0.06 & $\mathrm{Si}$ \\
0.64 & 0.94 & 0.86 & 1.42 & 0.7 & $\mathrm{P}$ \\
0.11 & 0.15 & 0.23 & 0.25 & 0.14 & $\mathrm{~S}$ \\
3.79 & 5.15 & 10.64 & 5.6 & 4.1 & $\mathrm{Cl}$ \\
5.51 & 9.65 & 11.65 & 10.9 & 6.17 & $\mathrm{~K}$ \\
0.41 & 0.95 & 0.29 & 1.68 & 0.5 & $\mathrm{Ca}$ \\
\hline
\end{tabular}

TABLE 2. EDXA analysis of some spots on the surface of CRBR after adsorption of lead ions

\begin{tabular}{cccccc}
\hline Spot 4 (wt \%) & Spot 3 (wt \%) & Spot 2 (wt \%) & Spot 1 (wt \%) & $\begin{array}{c}\text { Full area (wt } \\
\text { \%) }\end{array}$ & element \\
\hline 35.49 & 14.28 & 34.09 & 55.45 & 46.56 & $\mathrm{C}$ \\
18.79 & 0.57 & 2.26 & 7.54 & 23.29 & $\mathrm{~N}$ \\
26.05 & 34.92 & 4.18 & 24.35 & 19.69 & $\mathrm{O}$ \\
2.64 & 3.07 & 0.05 & 3.46 & 1.38 & $\mathrm{Na}$ \\
0.46 & 0.06 & 0.03 & 1.06 & 0.22 & $\mathrm{Mg}$ \\
- & 11.55 & - & 0.37 & - & $\mathrm{Al}$ \\
- & 20.79 & - & 0.03 & - & $\mathrm{Si}$ \\
0.49 & - & 3.38 & 1.19 & 0.89 & $\mathrm{P}$ \\
- & - & - & 0.01 & - & $\mathrm{S}$ \\
- & - & 43.12 & - & 6.2 & $\mathrm{Cl}$ \\
15.2 & 0.09 & 1.73 & 4.31 & 1.29 & $\mathrm{~Pb}$ \\
0.57 & 6.95 & 6.55 & 1.59 & 0.48 & $\mathrm{~K}$ \\
0.29 & 5.72 & 4.61 & 0.64 & - & $\mathrm{Ca}$ \\
\hline
\end{tabular}

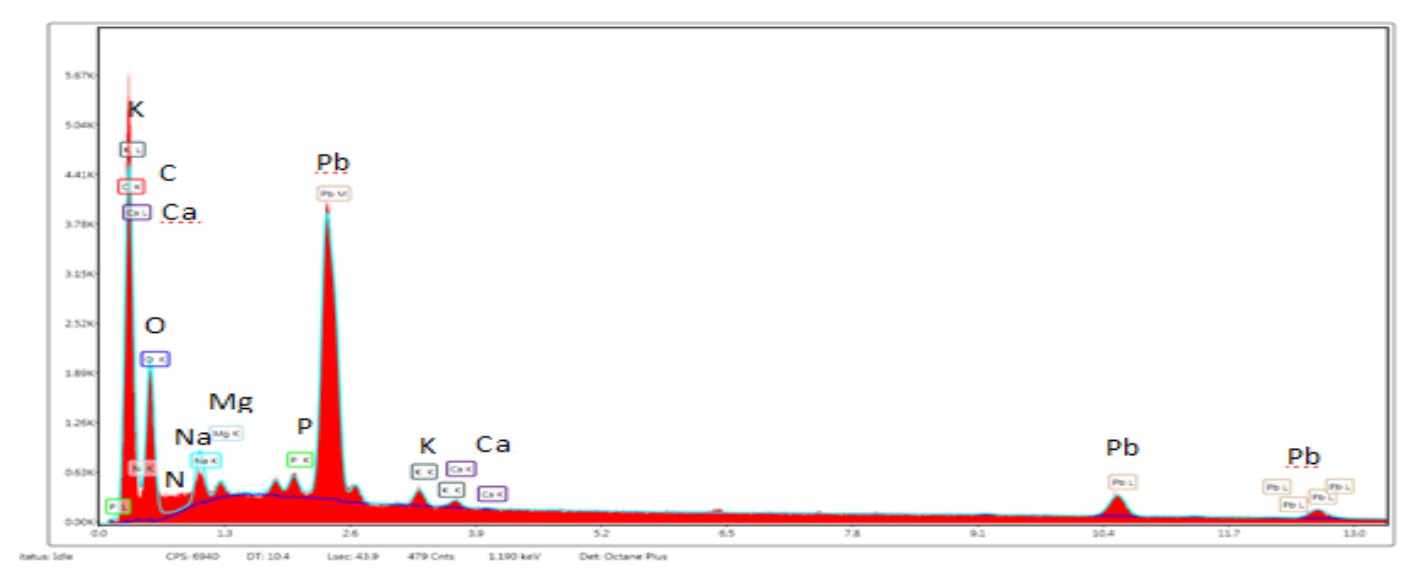

Fig. 2. Chemical composition of CRBR after adsorption by using EDXA analysis

Egypt. J. Chem. 62, No. 3 (2019) 
TABLE 3. Elemental structure of CRBR by using XRF

\begin{tabular}{cc}
\hline Elements & Concentration \\
\hline Non & main elements of concentration $>\% 10$ \\
$\mathrm{~K}$ & Main elements of concentration more than $1 \%$ and less than $10 \%$ \\
$\mathrm{Ca}, \mathrm{Cl}, \mathrm{Mn}, \mathrm{Fe}, \mathrm{Sr}, \mathrm{P}, \mathrm{S}$ & Elements of concentrations from $1 \%$ to $100 \mu \mathrm{g} / \mathrm{g}$ \\
$\mathrm{Cr}, \mathrm{Cu}, \mathrm{Ni}, \mathrm{Br}, \mathrm{Zn}, \mathrm{Rb}, \mathrm{Pb}, \mathrm{Ti}$ & Elements of concentrations of $(1-100) \mu \mathrm{g} / \mathrm{g}$ \\
$\mathrm{Non}$ & Trace elements of less than $1 \mu \mathrm{g} / \mathrm{g}$ \\
\hline
\end{tabular}

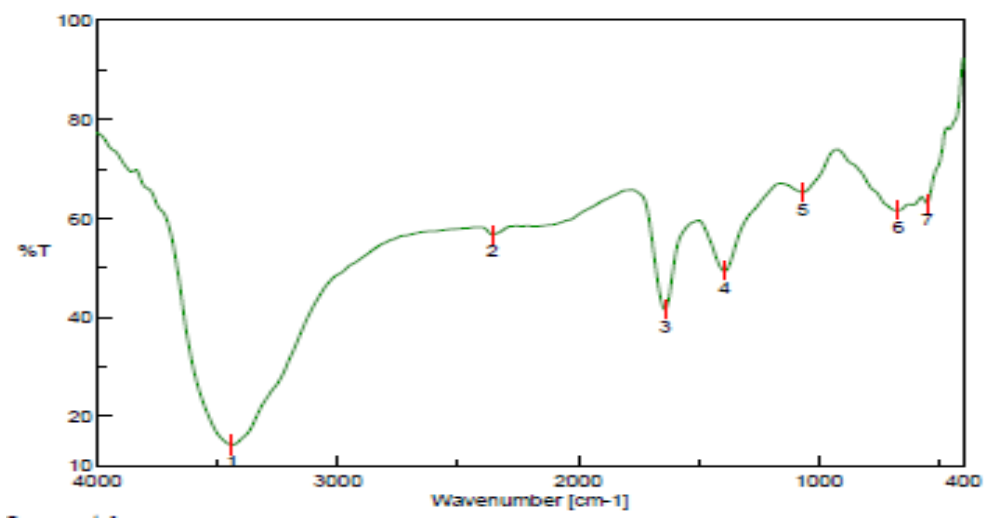

Fig. 3a. The FT-IR spectra of CRBR before adsorption of lead ions.

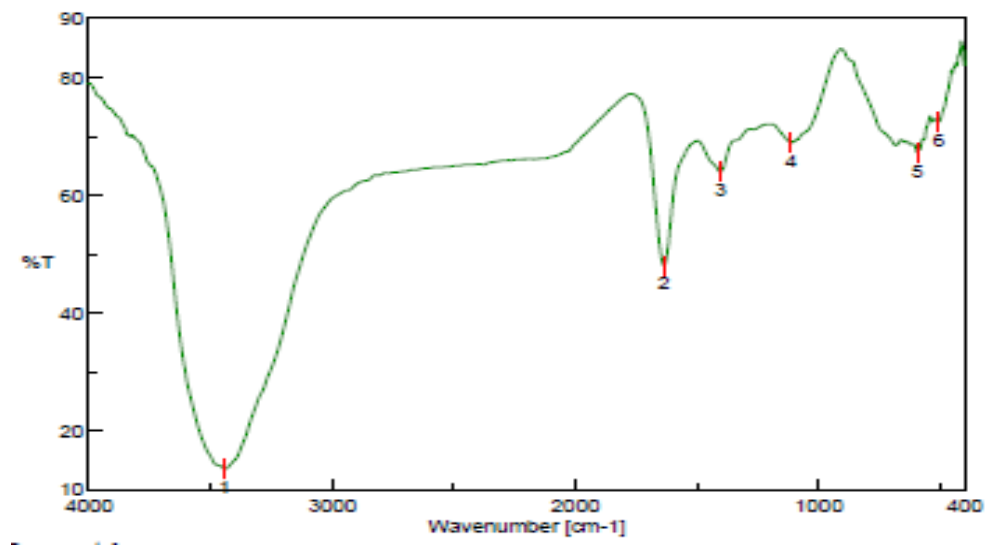

Fig. 3b. The FT-IR spectra of CRBR after adsorption of lead ions.

CRBR after adsorption of $\mathrm{Pb}(\mathrm{II})$ ions.

The main wave numbers of the peaks appearing in Fig. $3 a$ and $3 b$ are listed in Table 4.

\section{Effects of different experimental conditions \\ Effect of contact time}

Effect of contact time was studied in the range of (0.5-48) hrs by using a sample of $0.1 \mathrm{~g}$ of CRBR and $5 \mathrm{ml}$ of lead nitrate with $9.993 \mathrm{~m} . \mathrm{mol} / \mathrm{L}$ concentration of solution. The experimental results are presented in Fig. 4.

It was found from Fig. 4 that the removal percentage of lead ions increased with increasing the contact time and the equilibrium was attained at about (24) hrs, this result is in accordance with the references $[3,10]$.

Effect of adsorbent loading weight

The effect of adsorbent loading weight is presented in Fig. 5. The dependence of $\mathrm{Pb}$ (II) ions adsorption on the dose of adsorbent was studied by varying the mass of adsorbent in the range of 0.05 to $0.2 \mathrm{~g}$, whereas other parameters (concentration, contact time) were kept constant at room temperature. It can be inferred that the percentage removal of lead ions increases with increasing the dose of adsorbent from $0.05 \mathrm{~g}$ to $0.1 \mathrm{~g}$. However, 


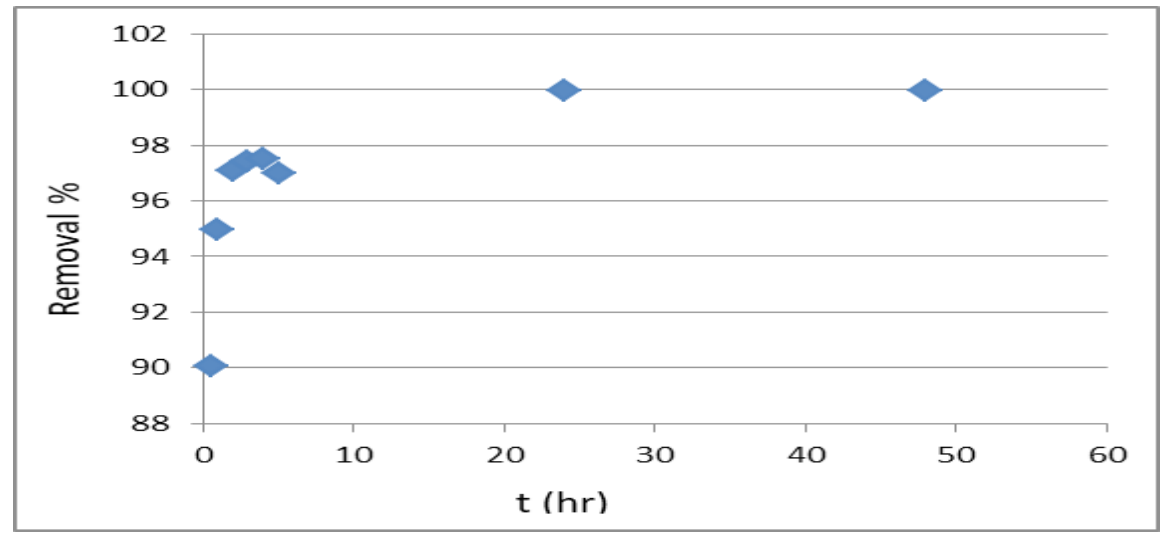

Fig. 4. Effect of contact time on $\mathrm{Pb}(\mathrm{II})$ ions adsorption by $\mathrm{CRBR}, \mathrm{C}_{0}=9.993 \mathrm{~m} . \mathrm{mol} / \mathrm{L}, \mathrm{m}=0.1 \mathrm{~g}$

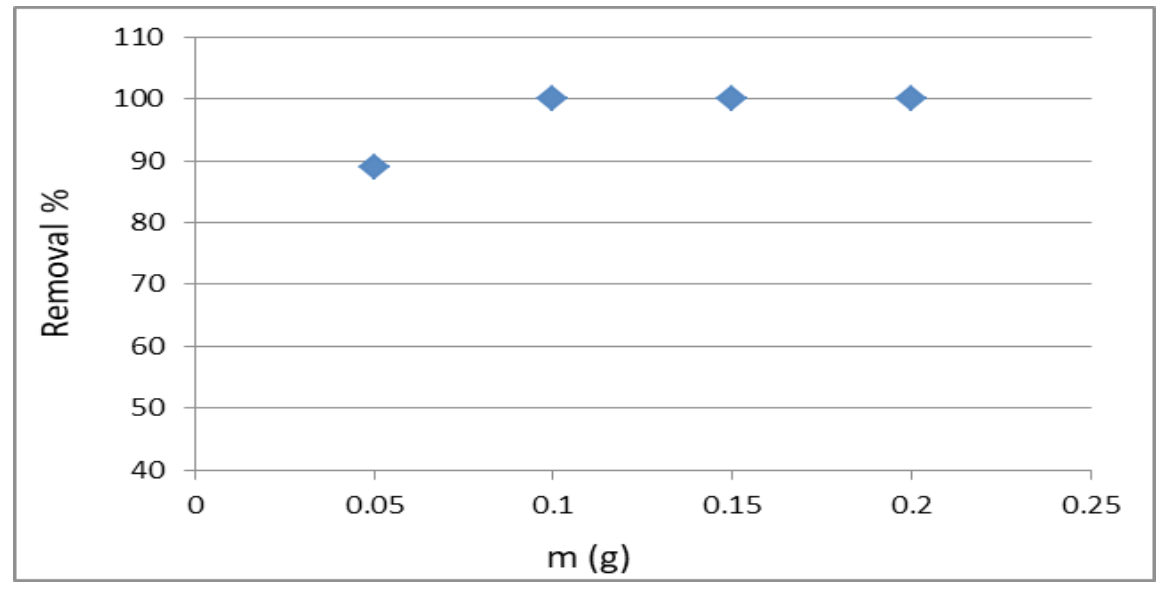

Fig. 5. Effect of adsorbent dose on removal of $\mathrm{Pb}(\mathrm{II})$ ions, $\mathrm{C}_{0}=9.993 \mathrm{~m} . \mathrm{mol} / \mathrm{L}, \mathrm{t}=48 \mathrm{hrs}$.

when the dose of adsorbent was increased from 0.1 to $0.2 \mathrm{~g}$ no significant increases in removal percentage were observed. This suggests that after a certain dose of adsorbent, the maximum adsorption is reached and hence the amount of ions bound to the adsorbent and the amount of free ions in the bulk remains constant even with further increasing of the dose of adsorbent. The increasing of $\mathrm{Pb}$ (II) ions removal percentage with the increasing of the dose of adsorbent is as a result of the availability of the active sites or surface area at higher doses of the adsorbent $[3,10]$.

\section{Effect of initial concentration}

In order to find the effect of $\mathrm{Pb}$ (II) ions concentration in aqueous solution on the adsorption process, tests were made at room temperature in the range of (4.997-9.993) m.mol/L of $\mathrm{Pb}$ (II) ions within a fixed time $2 \mathrm{hrs}$, The mass of CRBR was $0.05 \mathrm{~g}$ and the volume of lead solution was $5 \mathrm{ml}$. Figure 6 shows the adsorbed lead amount as a function of equilibrium lead concentration.

It is noticed from Fig. 6 that the amount of adsorbed lead increases with increasing equilibrium lead concentration

\section{Effect of the change of temperature}

Tests for adsorption of $\mathrm{Pb}(\mathrm{II})$ ions in aqueous solution by CRBR were made at different temperature $(20-50)^{\circ} \mathrm{C}$ when contact time, the dose of adsorbent and concentration of $\mathrm{Pb}(\mathrm{II})$ ions solution were $2 \mathrm{hrs}, 0.1 \mathrm{~g}, 9.993 \mathrm{~m} . \mathrm{mol} / \mathrm{L}$ respectively. Results of these tests are shown in Fig. 7.

It is clear from Fig. 7 that the percentage removal of $\mathrm{Pb}(\mathrm{II})$ ions is almost constant with 


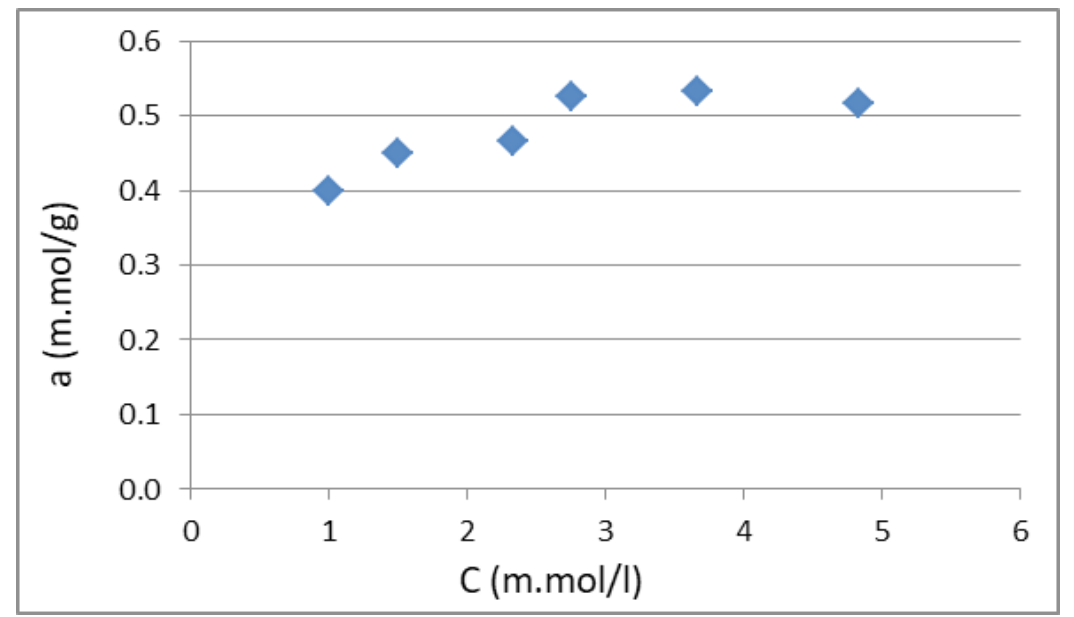

Fig. 6. Adsorbed lead amount as a function of equilibrium lead concentration $\mathrm{m}=0.05 \mathrm{~g}, \mathrm{t}=2 \mathrm{hrs}, \mathrm{C}_{0}=4.997-9.993$ $\mathrm{m} . \mathrm{mol} / \mathrm{L}$

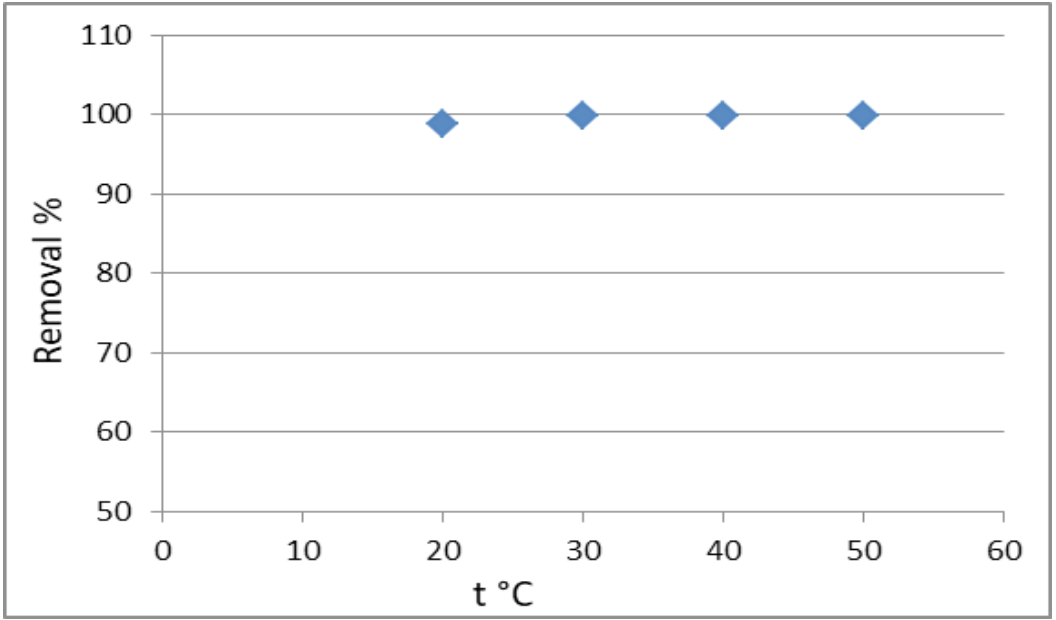

Fig. 7. Effect of temperature on Removal of lead ions, $t=2 \mathrm{hrs}, \mathrm{m}=0.1 \mathrm{gr}, \mathrm{C}_{0}=9.993 \mathrm{~m} . \mathrm{mol} / \mathrm{L}$.

the increasing of temperature. This indicates that the adsorption of $\mathrm{Pb}$ (II) ions on CRBR was chemisorption.

\section{Effect of $p H$}

The $\mathrm{pH}$ in solution is one of the most important parameters of adsorption of heavy metals. The adsorption of lead ions by CRBR at different $\mathrm{pH}$ values is presented in Fig. 8. The effect of $\mathrm{pH}$ was studied at room temperature by varying the $\mathrm{pH}$ of metallic solution from (2.1-5.3).

Removing of lead at lower $\mathrm{pH}$ was not observed. This result can be explained on the bases that at lower $\mathrm{pH}$ values, the $\mathrm{H}^{+}$ions were high and competed with the metal cation in the adsorption sites of the system [10]. By increasing
$\mathrm{pH}$, the negative charge density on the adsorbent increases due to deprotonation of metal binding sites, thus increasing metal adsorption. The maximum amount of removing $\mathrm{Pb}$ (II) ions was at $\mathrm{pH}=4.7$, whereas at $\mathrm{pH}$ higher than 5.3, lead ions were precipitated due to the formation of lead hydroxide [3].

\section{Adsorption isotherms}

The experimental data, for removing the lead ions by CRBR at different concentrations of lead solution, were analyzed by the well -known models given by Langmuir, Freundlich and Dubinin-Radushkevich models.

The Langmuir isotherm takes an assumption that the adsorption occurs at specific homogeneous 


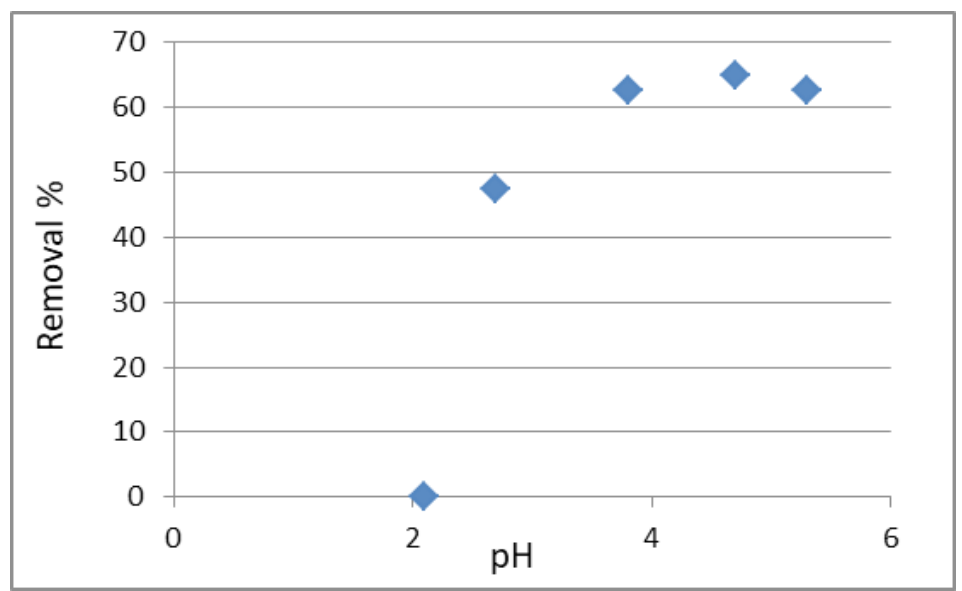

Fig. 8. Effect of $\mathrm{pH}$ on removal of lead ions, $\mathrm{t}=2 \mathrm{hrs}, \mathrm{m}=0.01 \mathrm{gr}, \mathrm{C}_{0}=5 \mathrm{~m} . \mathrm{mol} / \mathrm{L}$

sites within the adsorbent [3]. The general form of Langmuir equation is given as (1):

$$
a_{e}=\frac{a_{m} K_{L} C_{e}}{1+K_{L} C_{e}}
$$

Where:

$\mathrm{C}$ : The equilibrium metal ions concentration in solution $(\mathrm{m} \cdot \mathrm{mol} / \mathrm{L})$.

$\mathrm{a}, \mathrm{a}_{\mathrm{m}}$ : The amount of metal ions adsorbed on the carbon and the maximum metal ions uptake per unit mass of adsorbent, respectively (m.mol/g).

$\mathrm{K}_{\mathrm{L}}$ : Langmuir constant (L/m.mol).

The linear form of isotherm equation can be written as (2):

$$
\frac{1}{a_{e}}=\frac{1}{a_{m}}+\frac{1}{a_{m} \cdot K_{L} \cdot C_{e}}
$$

The parameters $a_{m}$ and $K_{L}$ can be determined from Fig. 9 which shows the plot of (1/a) versus $(1 / \mathrm{C})$

The Freundlich expression is an empirical equation derived for the heterogeneous surfaces [3]. The general form of Freundlich equation is (3):

$$
a_{\theta}=K_{F} \cdot C_{\theta}^{1 / n}
$$

Where:

$\mathrm{K}_{\mathrm{F}:}$ Freundlich constant $(\mathrm{lit})^{1 / \mathrm{n} / \mathrm{g}}(\mathrm{m} . \mathrm{mol})^{1 / \mathrm{n}-1}$

$\mathrm{n}$ : The adsorption intensity.

$\mathrm{C}$ : The equilibrium metal concentration in solution
(m.mol/L).

a: The amount of metal ions adsorbed per mass unite of the carbon $(\mathrm{m} \cdot \mathrm{mol} / \mathrm{g})$.

The linearized form of this model is given by equation (4):

$$
\log a_{\theta}=\log K_{F}+\frac{1}{n} \log C_{\theta}
$$

Where the intercept $\log \mathrm{K}_{\mathrm{F}}$ is a measure of adsorption capacity, and the slope $1 / \mathrm{n}$ is the intensity of adsorption [3]. The Freundlich adsorption models are presented in Fig. 10.

Dubinin-Radushkevich isotherm is generally applied to express the adsorption mechanism with a Gaussian energy distribution onto heterogeneous surfaces. This model has often successfully fitted high solute activities and intermediate range of concentration [22]

$$
\ln a_{e}=\ln a_{s}-k_{a d} \varepsilon^{2}
$$

Where $\mathrm{a}_{\mathrm{s}}$ is the theoretical saturation capacity (mol/g), $\varepsilon$ : Polanyi potential, which is equal to RT $\ln \left(1+1 / \mathrm{C}_{\mathrm{e}}\right), \mathrm{R}(\mathrm{J} / \mathrm{mol} . \mathrm{K})$ is the universal gas constant, $\mathrm{T}(\mathrm{K})$ is the absolute temperature, and $\mathrm{K}_{\mathrm{ad}}$ is a constant related to the mean free energy of adsorption per mole of adsorbate $\left(\mathrm{mol}^{2} / \mathrm{KJ}^{2}\right)$,

$$
E=\frac{1}{\sqrt{2 K_{a d}}}
$$

Where $\mathrm{k}_{\mathrm{ad}}$ is denoted as the isotherm constant and $\mathrm{a}_{\mathrm{s}}, \mathrm{K}_{\mathrm{ad}}$ can be determined by plotting $\ln \mathrm{a}_{\mathrm{e}}$ versus $\varepsilon^{2}$ (Fig. 11).

Dada et al [22] assumed that if the magnitude

Egypt. J. Chem. 62, No. 3 (2019) 


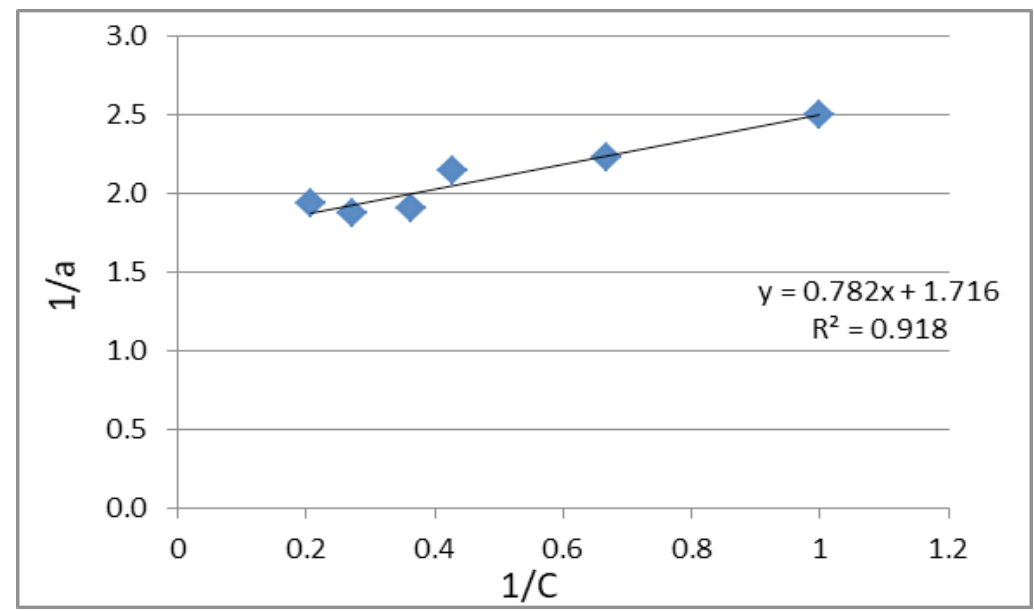

Fig. 9. Application of langmuir isotherms for $\mathrm{Pb}(\mathrm{II})$ ions adsorption, $\mathrm{m}=0.05 \mathrm{~g}, \mathrm{t}=\mathbf{2} \mathrm{hrs}$.

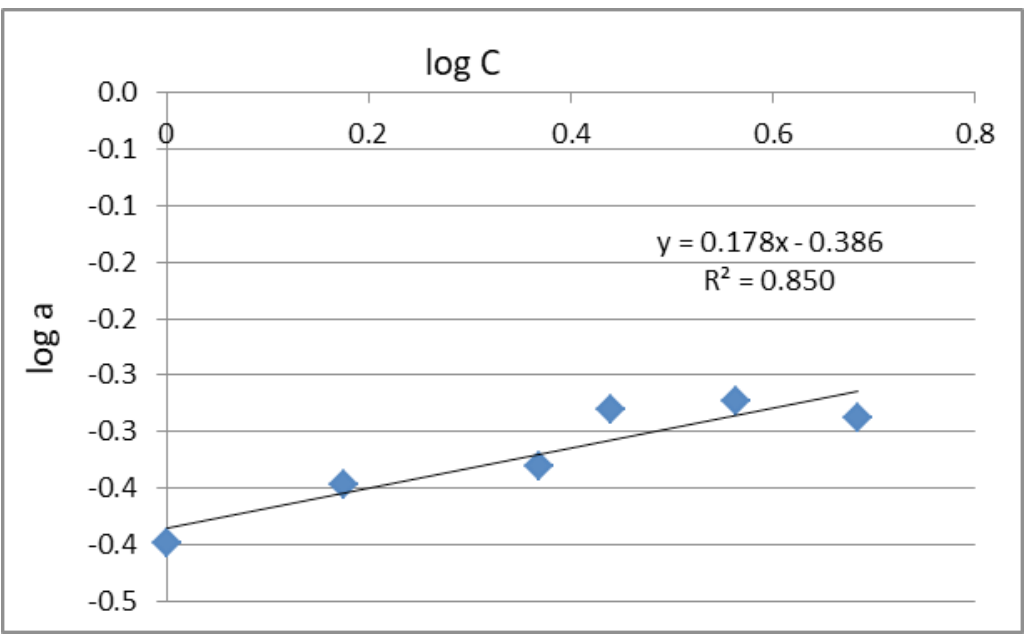

Fig. 10. Application of freundlich isotherms for $\mathrm{Pb}(\mathrm{II})$ ions adsorption, $\mathrm{m}=\mathbf{0 . 0 5} \mathrm{g}, \mathrm{t}=\mathbf{2} \mathrm{hrs}$.

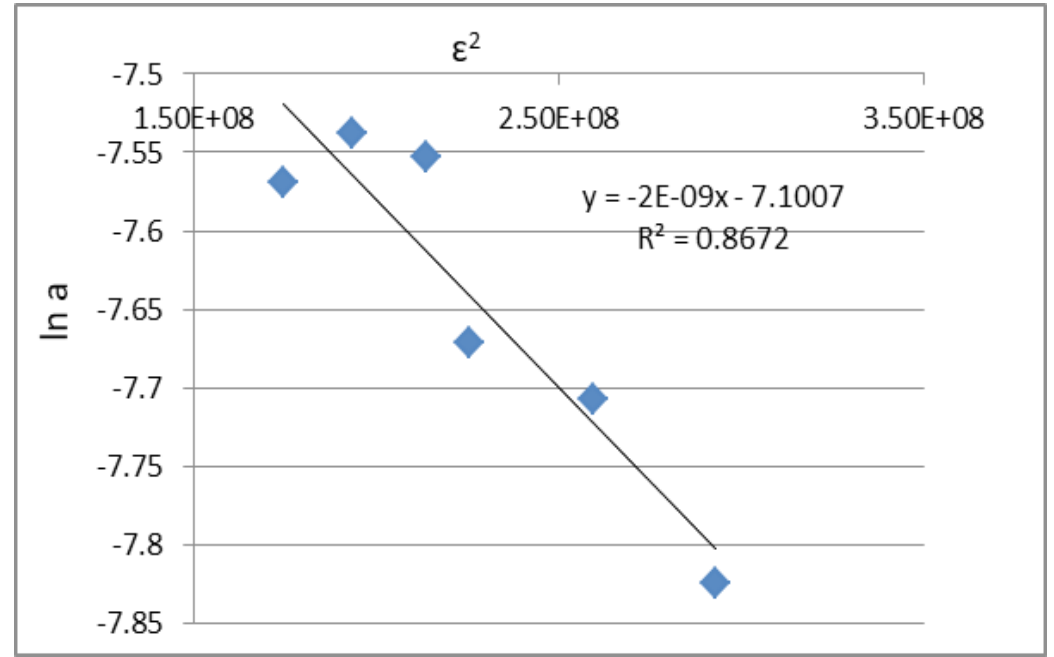

Fig. 11. Application dubinin-Radushkevich isotherms for $\mathrm{Pb}(\mathrm{II})$ ions adsorption, $\mathrm{m}=0.05 \mathrm{~g}$, $\mathrm{t}=\mathbf{2} \mathrm{hrs}$. 
of $\mathrm{E}$ is between 8 and $16 \mathrm{KJ} / \mathrm{mol}$, the adsorption process proceeds by ion exchange while for $\mathrm{E}<8$ $\mathrm{KJ} / \mathrm{mol}$ the adsorption process is of a physical nature [23], in this study the value of $\mathrm{E}$ in Table 3 is calculated as $15.811 \mathrm{KJ} / \mathrm{mol}$, this may be an indication that ion exchange reaction is taking place along with the adsorption process

It was found from Fig. 9-11 that the experimental data fitted Langmuir isotherm equation more than other isotherms. Values of parameters for Langmuir, Freundlich and Dubinin-Radushkevich isotherms are written in Table 5.

Separation factor $R_{L}$ can be used to predict affinity between the sorbate and sorbent in the adsorption system according to the studies $[3,24]$. The expression of separation factor in the dimensionless form of Langmuir isotherm is

$\mathrm{R}_{\mathrm{L}}=1 /\left(1+\mathrm{K}_{\mathrm{L}} \cdot \mathrm{C}_{0}\right)$, where $\mathrm{C}_{0}$ is the initial concentration of metal ion, $\mathrm{K}_{\mathrm{L}}$ is the Langmuir constant.

The characteristics of $R_{L}$ value indicates the nature of adsorption as unfavourable $\left(R_{L}>1\right)$, linear $\left(\mathrm{R}_{\mathrm{L}}=1\right)$, favourable $\left(0<\mathrm{R}_{\mathrm{L}}<1\right)$, and irreversible $\left(R_{L}=0\right)$, in the whole studied concentration (4.997-
9.993) m.mol/L of metal ions the separation factor $R_{L}$ is between (0.0436-0.0836 )and it is less than 1 indicating the favourable adsorption.

\section{Adsorption Kinetics}

The kinetics of the adsorption of lead ions was studied by applying pseudo second order model as shown in Fig. 12. Pseudo second order model expression is given in the following equation:

$$
\frac{t}{a_{t}}=\frac{1}{k_{2} a_{e}^{2}}+\frac{1}{a_{e}} t
$$

Where $a_{t}, a_{e}(\mathrm{~m} . \mathrm{mol} / \mathrm{g})$ are the amount of lead ions adsorbed by $1 \mathrm{~g}$ of the carbon within time (hr) and at equilibrium respectively, $\mathrm{k}_{2}$ L.(m. mol.hr $)^{-1}$ is the rate constant of adsorption in the pseudo second order reaction

The constants $a_{e}$ and $k_{2}$ were calculated from equation of plot $\mathrm{t} / \mathrm{a}_{\mathrm{t}}$ versus $\mathrm{t}$ and Table 6 shows the related values.

It is concluded from Table 6 that the adsorption of lead ions onto CRBR fitted pseudo second order reaction and the value of $\left(a_{e}\right)$ which was calculated according to pseudo second order model was close to experimental value.

TABLE 4. Some important functional groups with their wave numbers in FT-IR spectrum for CRBR before and after adsorption of $\mathrm{Pb}$ (II)

\begin{tabular}{cccc}
\hline $\begin{array}{c}\text { Wave number } \\
\mathbf{c m}^{-1} \text { after } \\
\text { adsorption }\end{array}$ & $\begin{array}{c}\text { Wave number } \mathbf{c m}^{-1} \\
\text { Before adsorption }\end{array}$ & Functional groups & References \\
\hline 3442 & 3440 & $\mathrm{OH}$ & {$[19]$} \\
- & 2356 & $\mathrm{C} \equiv \mathrm{C}$ & {$[16],[19]$} \\
1635 & 1639 & $\mathrm{C}=\mathrm{C}$ & {$[16],[19]$} \\
1403 & 1391 & OH bending & {$[18],[20],[19]$} \\
1112 & 1066 & C-O stretching vibration & {$[16],[19]$} \\
- & $668-549$ & C-X or M-X & {$[19]$} \\
$593-504$ & - & Pb-O & {$[21]$} \\
\hline
\end{tabular}

TABLE 5. Langmuir, Freundlich and Dubinin-Radushkevich parameters for adsorption of $\mathrm{Pb}(\mathrm{II})$ on CRBR.

\begin{tabular}{cccccccccc}
\hline \multicolumn{2}{c}{ Langmuir parameters } & \multicolumn{3}{c}{ Freundlich parameters } & \multicolumn{4}{c}{ Dobinin-boliani parameters } \\
\hline $\begin{array}{c}\mathbf{a}_{\mathbf{m}} \\
(\mathbf{m} . \mathbf{m o l} / \mathbf{g})\end{array}$ & $\begin{array}{c}\mathbf{K}_{\mathbf{L}} \\
(\mathbf{l i t} / \mathbf{m o l})\end{array}$ & $\mathbf{R}^{2}$ & $\mathbf{n}$ & $\begin{array}{c}\mathbf{K}_{\mathrm{F}} \\
(\mathbf{l i t})^{\mathbf{m} / \mathbf{n}} / \mathbf{g}\end{array}$ & $\mathbf{R}^{2}$ & $\begin{array}{c}\mathbf{E}(\mathbf{K J} / \\
\mathbf{m o l})\end{array}$ & $\mathbf{a}_{\mathbf{s}}(\mathbf{m o l} / \mathbf{g})$ & $\begin{array}{c}\mathbf{K}_{\mathrm{ad}} \\
\left(\mathbf{m o l}^{2} /\right. \\
\left.\mathbf{J}^{2}\right)\end{array}$ & $\mathbf{R}^{2}$ \\
\hline 0.583 & 2194.373 & 0.918 & 5.618 & 0.411 & 0.85 & 15.811 & 0.000825 & $2 \mathrm{E}-09$ & 0.867 \\
\hline
\end{tabular}




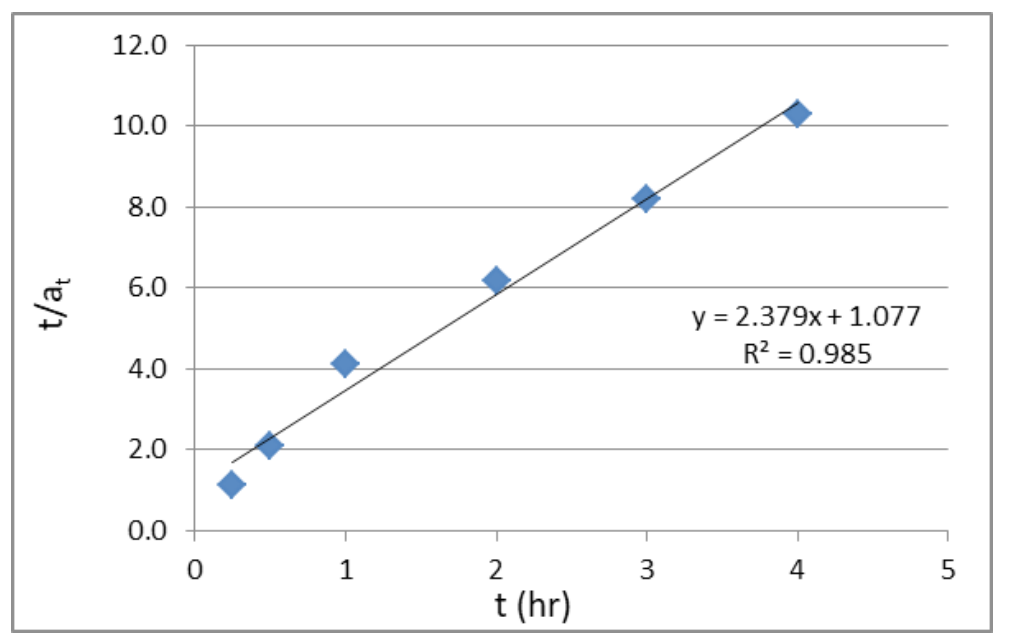

Fig. 12. Application of pseudo second order model on adsorption of lead by CRBR.

TABLE 6. The rate constant and equilibrium amount of lead (II) for pseudo second order model

\begin{tabular}{cccc}
\hline $\mathbf{R}^{2}$ & $\mathbf{k}_{\mathbf{2}}(\mathbf{m} \cdot \mathbf{m o l} \cdot \mathbf{h r})^{-1} \cdot \mathbf{L}$ & $\mathbf{a}_{\mathrm{e}}(\mathbf{m} \cdot \mathbf{m o l} / \mathbf{g})$ & $\mathbf{a}_{\mathrm{e}} \exp (\mathbf{m} \cdot \mathbf{m o l} / \mathbf{g})$ \\
\hline 0.985 & 5.264 & 0.420 & 0.500 \\
\hline
\end{tabular}

Mechanism of adsorption of pb(II) ions on CRBR

Our experimental results may be explained by the following mechanism
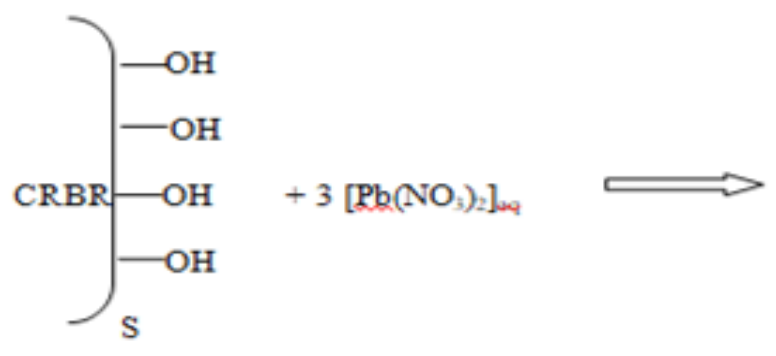

Where: $\mathrm{S}$ is the surface of CRBR, $\mathrm{OH}$ are hydroxyl groups existing on the surface of CRBR. The $\mathrm{pH}$ of lead solution during the adsorption process was observed, where the initial concentration of lead nitrate solution had a $\mathrm{pH}=5.27$ and within adsorption process the $\mathrm{pH}$ increased to 7-8. The mechanism of this reaction can be suggested with $\left[\mathrm{Pb}_{3}(\mathrm{OH})_{4}\right]^{+2}$ or $\left[\mathrm{Pb}_{6} \mathrm{O}(\mathrm{OH})_{6}\right]^{+4}[25]$.

Desorption of the $\mathrm{Pb}(\mathrm{II})$ adsorbed from the surface of CRBR

The $\mathrm{Pb}(\mathrm{II})$ ions complex deposited in a layer bounded to the surface of CRBR as a result of the adsorption process. The previous material was treated with $5 \mathrm{ml}$ of acetic acid solution (1
$\mathrm{N}$ ), left for a half an hour and then filtrated for the measurement of the $\mathrm{Pb}^{+2}$ concentration ions by using the atomic absorption device. The percentage of recovery of $\mathrm{Pb}$ (II) was $87.466 \%$ of

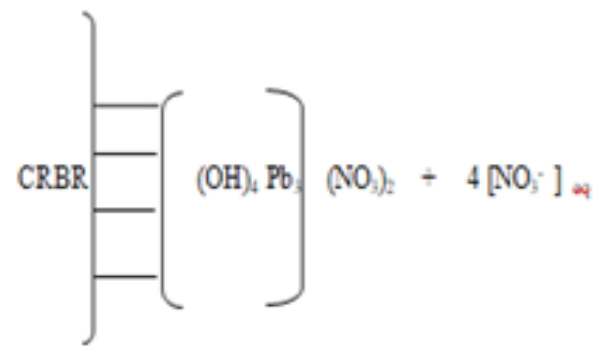

adsorbed $\mathrm{Pb}(\mathrm{II})$ on the surface of CRBR.

\section{Adsorption of NO3-ions by CRBR}

The concentration of $\mathrm{NO}_{3}^{-}$ions in the solution before and after adsorption of lead ions by CRBR was measured by the method mentioned in the reference [26] and it was found that the $\mathrm{NO}_{3}^{-}$ions were adsorbed on the surface of CRBR and the percentage of $\mathrm{NO}_{3}{ }^{-}$adsorption increased with the increasing of contact time, temperature, and the dose of adsorbent. The maximum removal for $\mathrm{NO}_{3}$ - ions was $38 \%$ at contact time $24 \mathrm{hrs}, 0.1 \mathrm{~g}$ the dose of adsorbent at room temperature.

\section{Conclusions}

Single and non-modified carbon from red 
beet roots has been prepared in this work for the removal of lead ions from aqueous solution.

The change of temperature had no effect on $\mathrm{pb}(\mathrm{II})$ ions adsorption.

The removal percentage of lead ions increased with increasing the dose of adsorbent and contact time.

A $87.446 \%$ recovery of the adsorbed pb(II) ions on CRBR has been reached by use of little amount with acetic acid solution $1 \mathrm{~N}$.

Adsorption of lead ions onto CRBR fitted the kinetic of pseudo second order reaction

A mechanism for the formation of the complex surface structure of the process has been proposed.

It can be concluded that the carbon of red beet roots was effective as for removal of lead ions from aqueous solution with a percentage of $99.99 \%$ accompanied with a partial removal of $\mathrm{NO}_{3}{ }^{-}$ions with a percentage of $38 \%$.

\section{Acknowledgement}

This research was funded by scientific affairs in Damascus University

The authors would like to thank Dr. Hanan Al chaghouri for her contribution to English writing of manuscript.

\section{References}

1. Abas, S.N.A., Ismail, M.H.S., Kamal, M.L., Izhar, S., Adsorption process of heavy metals by lowcost adsorbent A review. World Applied Sciences Journal, 28, 1518-1530 (2013).

2. Luma, A., Mohammed, A., Adsorption of lead (II) from industrial waste water by tea leaf leaves as adsorbent. International Journal of Chem Tech Research, 10, 829-836 (2017).

3. Singanan, M., Removal of lead (II) and cadmium (II) ions from wastewater using activated bio carbon. Science Asia, 37, 115-119 (2011).

4. Pehlivan, E., Yanik, B.H., Ahmetli, G., Pehlivan, M., Equilibrium isotherms studies for the uptake of cadmium and lead ions onto sugar beet pulp. Bioresource Technology, 99, 3520-3527 (2008).

5. Raungsomboon, S., Chidthaisong, A., Bunnag, B., Inthron, D., Harvey, N.W., Removal of lead $\mathrm{Pb}^{+2}$ by the Cyanobacterium Gloeocapsa sp. Bioresour, Technol, 99, 5650-5658 (2007).

6. Raikar, R.V., Correa, S., Ghorpade, P., Removal of Lead (II) from Aqueous Solution Using Natural and Activated Rice Husk. International Research Journal of Engineering and Technology, 2 (2015).

7. Karthika, C., Vennilamani, N., Pattabhi, S., Sekar, M., Utilization of Sago Waste as an Adsorbent for the Removal of $\mathrm{Pb}(\mathrm{II})$ from Aqueous Solution Kinetic and Isotherm Studies. 2, 1867-1879 (2010).

8. Wan, S., Ma, Z., Zue, Y., Ya, M., Sorption of Lead (II) Cadmium(II) and Copper(II) Ions from Aqueous Solutions Using Tea Waste. American Chemical Society, 53, 3629-3635 (2014).

9. Boudrahem, F., Aissani- Benissad, F., Soualah, A., Adsorption of Lead(II) from Aqueous Solution by Using Leaves of Date Trees As an Adsorbent. American Chemical Society, 56, 1804-1812 (2011)

10. Abdel-Ghani, N.T., Hefny, M., El-Chaghaby, G.A.F., Removal of lead from aqueous solution using low cost abundantly available adsorbents. Environ. Sci. Tech., 4, 67-73(2007).

11. Yarkandi, N.H., Removal of lead (II) from waste water by adsorption. International Journal of Current Microbiology and Applied Science, 3, 207-228 (2014).

12. Rashed, N.M., Soltan, M.E., Ahmed, M.M., and Abdou, A., Heavy Metals Removal from Wastewater by Adsorption on Modified Physically Activated Sewage Sludge. Arc Org Inorg. Chem. Sci., 1(1), 1-8 (2018).

13. Narayanan, A. Lakshmi, Govindhan, R., Dhamodaran, M., Solomon, J. Samu, Removal of Dyes and Heavy Metals from Tannery Waste Water by Using Activated Lawsonia inermis Carbon. Advanced Science, Engineering and Medicine, 10(2), 119-128 (2018).

14. Amer, H., El-Gendy, A., El-Haggar, S., Removal of lead (II) from aqueous solutions using rice straw, Water Science and Technology, 76(5), 10111021 (2017).

15. Enkhzaya, S., Shiomori, K., and Oyuntsetseg, B., Removal of Heavy Metals from Aqueous Solution by Adsorption using Livestock Biomass of Mongolia. Journal of Environmental Science and Technology, 10(3), 107-119 (2017).

16. Yusoff, S.N.M., Kamari, A., Removal of $\mathrm{Cu}(\mathrm{II})$ $\mathrm{Pb}(\mathrm{II}) \mathrm{Zn}$ (II) ions from aqueous solution using agricultural wastes adsorption and characterization studies. Journal of Environmental Protection, 5, 289-300 (2014).

17. Energy table for EDS analysis, jeol, https://www. unamur.be/services/microscopie/sme-documents/ Energy-20table-20for-20EDS-20analysis-1.pdf, (accessed 8 November 2017). 
18. A. Kzitcina, N.B. Koupletskaya, Application of $U V, I R, N M R$, and Mass spectrometry in Organic Chemistry, Moscow University publishment, 2 Edition (1979).

19. Stuart, B.H., Infrared Spectroscopy: Fundamentals and Applications. Chichester, West Sussex, England; Hoboken, NJ: J. Wiley (2004).

20. F.A. Miller, C.H. Wilkins, Infrared Spectra and Characteristic Frequencies of Inorganic ions, Analytical Chemistry. 24, 1254-1258 (1952).

21. Sumin, V.I.; Portilla, Infrared Spectroscopic Investigation of the structure of some natural arsenates and the nature of $\mathrm{H}$-bonds in their structures. Canadian Mineralogist, 12, 262-268 (1974).

22. Dada, A.O., Olalekan, A.P., Olatunya, A.M., Dada, O., Langmiur, Freundlich, Temkin and DobininRadoushkevich Isotherms Studies of Equilibrium Sorption of $\mathrm{Zn}^{+2}$ unto Phosphoric Acid Modified Rice Husk. IOSR Journal of Applied Chemistry, 3, 38-45 (2012).
23. Altundogan, H.S., N.E. Arslan, F. Tumen, Copper Removal from aqueous solutions by sugar beet pulp treated by $\mathrm{NaOH}$ and citric acid, Journal of Hazardous Materials. 149, $432-439$ (2007).

24. Foo, K.Y., Hameed, B.H., Insights into the modeling of adsorption isotherm system. Chemical Engineering Journal, 156, 2-10 (2010).

25. Susan, M., Grime, Simon, R., Johnston and Isaac Abrahams, Characterisation of the predominant low-pH lead (II)-hydroxo cation, $\left[\mathrm{Pb}_{4}(\mathrm{OH})_{4}\right]^{+4}$, crystal structure of $\left[\mathrm{Pb}_{4}(\mathrm{OH})_{4}\right]\left(\mathrm{NO}_{3}\right)_{4}$ and the implications of basic salt formation on the transport of lead in aqueous environment. J. Chem. Soc., 1, 2081-2086 (1995).

26. CESP, Standard Methods for the Examination of Water and Wastewater, thirded, Beijing, 258-268 (2002).

Received 24/5/2018;

accepted $9 / 10 / 2018$

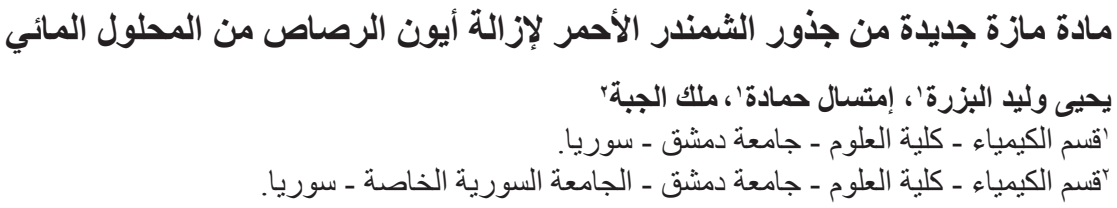

يهذف هذا البحث إلى إزالة أيون الرصاص من المحلول المائي باستخدام فحم جذور الثمندر الأحمر (CRBR).

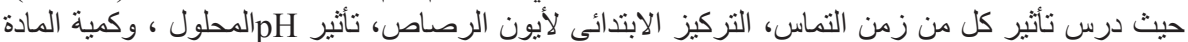

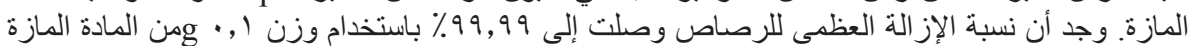

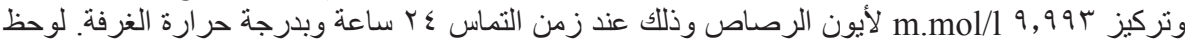
أن عملية امتز از أيون الرصاص على على الفحم CRBR ذات طبيعة كيميائية وتتبع تفاعل المرتبة الثانية الكاذبة.

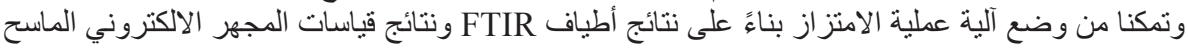

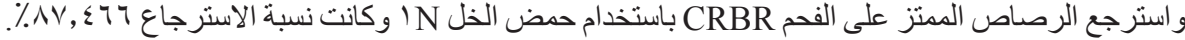

